\title{
Effect of storage time on colorimetric, physicochemical, and lipid oxidation parameters in sheep meat sausages with pre-emulsified linseed oil
}

\author{
Thamirys Lorranne Santos LIMA ${ }^{1 *}$, Gilmar Freire da COSTA ${ }^{1}$, George Rodrigo Beltrão da CRUZ ${ }^{1}$, \\ Íris Braz da Silva ARAÚJO ${ }^{1}$, Neila Lidiany RIBEIRO ${ }^{2}$ (D), Valquiria Cardoso da Silva FERREIRA ${ }^{1}$, \\ Fabio Anderson Pereira da SILVA ${ }^{1}$, Edvaldo Mesquita BELTRÃO FILHO ${ }^{1}$
}

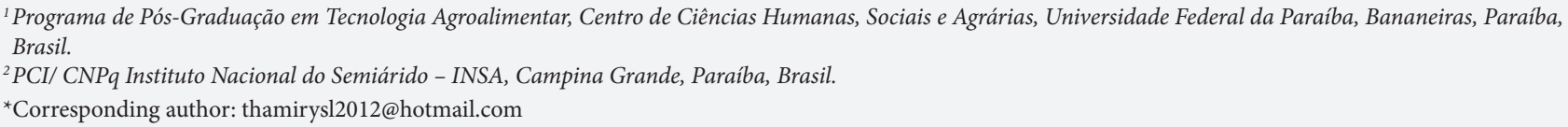

\begin{abstract}
This study's objective was to evaluate the effect of storage time $\left(-18 \pm 1{ }^{\circ} \mathrm{C} / 60\right.$ days $)$ under colorimetric, physicochemical, and lipid oxidation parameters in sheep meat sausages with oil pre-emulsified linseed to replace animal fat. Five formulations have been developed; the control sausage (0\%) and four fat replacement levels with pre-emulsified linseed oil: 10, 20, 30, and 40\%. Color analysis $\mathrm{s}\left(\mathrm{L}^{*}, \mathrm{a}^{*}\right.$ and $\left.\mathrm{b}{ }^{*}\right)$, determination of the total colorimetric difference (CD), water activity (Aw), pH, moisture, water retention capacity (WRC), and lipid oxidation through the number of substances reactive to thiobarbituric acid (TBARS), where all analysis were determined at intervals of 0,20, 40 and 60 days of storage. The treatment, the storage time, and the interaction between these factors significantly affected $(\mathrm{P}<.0001)$ most of the studied parameters. The TBARS values were affected by the treatment $(\mathrm{P}<.0001)$ and by the storage days $(\mathrm{P}<.0001)$, with an interaction between these factors $(\mathrm{P}<.0001)$. However, it is suggested that the replacement of animal fat with pre-emulsified linseed oil was a viable strategy without causing detrimental effects on the product's quality during the storage period.
\end{abstract}

Keywords: luminosity; TBARS; vegetable oils.

Practical Application: Consumers are opting for a healthier and more innovative eating style, being more aware of the relationship between diet and health. In this context, the meat industry is looking for new formulations of meat products that may come to meet this target audience, and also with the objective of promoting greater value addition to meat and the new reformulated product. Thus, the lipid reformulation of sheep meat sausages using pre-emulsified linseed oil becomes a highly viable and innovative alternative, allowing to increase the sector's competitiveness and meet consumer demands. However, this research presents a new innovative meat product, with high protein and low lipid contents, in addition to presenting storage stability up to 60 days $\left(-18^{\circ} \mathrm{C}\right)$.

\section{Introduction}

Sheep meat is widely consumed worldwide because of its excellent nutritional characteristics. However, despite its nutritional quality, its consumption in the fresh form still causes some restrictions, with industrialization being a possible strategy to promote added value to this raw material. (Teixeira et al., 2019). Thus, sausage is highly consumed by all social classes among meat products due to its low production cost and quick and easy preparation. However, during the processing of sausages, due to the addition animal fat, there is a predominance of saturated fatty acids, which, if consumed in excess, become harmful to human health (Sousa et al., 2017; Zeng et al., 2019).

As a way of promoting a change in these products' lipid constitution, an alternative would be to reduce or replace animal fat with other sources that can be considered healthier, such as vegetable oils, since they have a lower proportion of saturated fatty acids and a higher proportion of mono and polyunsaturated fatty acids (Inmanee et al., 2019). Among vegetable oils, linseed oil would be a good option since, according to Rallidis et al. (2003) and Mozaffarian et al. (2005), linseed has an excellent profile polyunsaturated fatty acid, which can provide the body with several benefits. These reasons justify its use as an ingredient in meat derivatives.

Thus, taking into account the process of lipid reformulation through the inclusion of vegetable oils in meat products, we have that the oil pre-emulsification technique with a non-meat protein is a process of producing oil in water emulsion where it this process can increase the stability of the emulsion, make the ingredients more evenly dispersed in meat products such 
as sausages, in addition to reducing the chances of the oil in the physical form being physically separated from the product structure, so that it remains stable in all conditions during the processing, storage and consumption (Kang et al., 2016; Qi et al., 2020).

Pre-emulsified linseed oil to replace animal fat in sheep meat sausages promoted specific characteristics for emulsion systems in the microstructure, resulting in more compact and firm sausages (Lima et al., 2021). The modified sausages have a high protein content, low lipid value, high water retention capacity, and better emulsion stability, technological characteristics desired for this type of product, both by the consumer and the food industry (Garcia-Santos et al., 2019). The lipid reformulation process did not affect oxidation rates, indicating that sheep sausage can be produced with pre-emulsified linseed oil up to a concentration of $40 \%$ without this process causing any deleterious effects on the physicochemical aspect and the quality of the final product (Lima et al., 2021). In this context, aspects related to the changes in these products during the storage period are of great interest for investigating quality. Thus, aspects such as shelf life need to be evaluated and considered to obtain a more precise and more objective understanding of replacing fat with vegetable oils in meat products. Thus, this research's objective was to evaluate the effect of storage on colorimetric, physicochemical, and lipid oxidation parameters in sheep meat sausages with preemulsified linseed oil.

\section{Material and methods}

\subsection{Sausage manufacturing process}

To improve the stability of linseed oil in sausages, the oil was pre-emulsified with isolated soy protein (ISP) supplied by Glamfoods Comércio de Alimentos Eireli (Ipiranga, São Paulo, Brazil) according to the procedures described by (DelgadoPando et al., 2012) with some modifications, where the emulsion was prepared with one part of the oil and two parts of isolated soy protein [oil/ISP (1:2)]. This mixture rested for $5 \mathrm{~min}$ until it was added to the meat masses. Sheep meat and fat were purchased from a local market (Solânea, Brazil). For this study, five different formulations were made: the control (CON) sausage (elaborated with animal fat) and sausages with 10, 20, 30, and $40 \%$ of linseed oil.

Initially, the external fat, intermuscular fat, connective tissue, nodules, and tendons were removed from the sheep meat, and then, it was ground in an industrial grinder (Braesi/ BMC-05, São Paulo, Brazil) with a $5 \mathrm{~mm}$ disk. After the meat was prepared, the other ingredients were weighed and homogenized by hand (except animal fat and oil emulsion), which were then added according to the pre-established quantities. During the manual mixing of the ingredients (Table 1) (Lima et al., 2021), with the meat, the emulsion temperature was maintained at $4{ }^{\circ} \mathrm{C}$ (refrigeration temperature), which was achieved with ice.

The mixture was taken to the cutter METVISA $^{\circledast}$ type CUT-3, Rio Grande do Sul, Brazil) until the formation of a completely homogeneous mass for approximately $3 \mathrm{~min}$, where the emulsion's final temperature did not exceed $10^{\circ} \mathrm{C}$. The meat masses were stuffed in artificial collagen wrappers $(24 \mathrm{~mm}$ in diameter) and cooked until the internal temperature of $74^{\circ} \mathrm{C}$. The sausages were not smoked. After cooking, the sausages were cooled in drinking water at $15^{\circ} \mathrm{C}$ for $15 \mathrm{~min}$, and then they were stored in a cold chamber at $4^{\circ} \mathrm{C}$ until the sausages reached an internal temperature of $5{ }^{\circ} \mathrm{C}$. Representative samples of each formulation were taken and analyzed periodically at intervals of $0,20,40$ and 60 days. A total of 240 samples were analyzed ( 5 treatments $\mathrm{x} 4$ periods $\mathrm{x} 6$ samples and 2 repetitions).

\subsection{Determination of physicochemical parameters of sheep meat sausages}

According to the Association of Official Analytical Chemistry (Association of Official Analytical Chemists, 2010), the analysis of moisture, protein, and ash was performed by gravimetry (methods 925.23 and 991.20), whereas the lipids were determined following the method proposed by Folch et al. (1957). The $\mathrm{pH}$ was measured in $24 \mathrm{~h}$ post mortem using a digital potentiometer

Table 1. Formulation of the sheep meat sausages.

\begin{tabular}{|c|c|c|c|c|c|}
\hline \multirow{2}{*}{ Ingredients $\left({\left.\mathrm{g} 100 \mathrm{~g}^{-1}\right)}^{-1}\right.$} & \multicolumn{5}{|c|}{ Levels of inclusion of linseed oil (\%) } \\
\hline & 0 & 10 & 20 & 30 & 40 \\
\hline Sheep meat & 60.0 & 60.0 & 60.0 & 60.0 & 60.0 \\
\hline Animal fat & 15.0 & 13.5 & 12.0 & 10.5 & 9.0 \\
\hline Linseed oil & 0.0 & 1.5 & 3.0 & 4.5 & 6.0 \\
\hline Healing salt & 0.015 & 0.015 & 0.015 & 0.015 & 0.015 \\
\hline Sodium Erythorbate & 0.05 & 0.05 & 0.05 & 0.05 & 0.05 \\
\hline Cassava starch & 2.0 & 2.0 & 2.0 & 2.0 & 2.0 \\
\hline Sodium chloride & 1.80 & 1.80 & 1.80 & 1.80 & 1.80 \\
\hline White pepper & 0.20 & 0.20 & 0.20 & 0.20 & 0.20 \\
\hline Garlic powder & 0.30 & 0.30 & 0.30 & 0.30 & 0.30 \\
\hline Annatto dye & 0.002 & 0.002 & 0.002 & 0.002 & 0.002 \\
\hline
\end{tabular}


(DIGIMED, model pH 300 M, São Paulo, Brazil) equipped with a glass electrode, where $5 \mathrm{~g}$ of the crushed sausages were homogenized in $50 \mathrm{ml}$ of deionized water (Choi et al., 2010). At the start of the measurements, the pHmeter was calibrated using solutions with $\mathrm{pH}$ values of 4 and 7 (Crison, Lainate, Italy) and was also automatically calibrated for the sausage temperature before each measurement. All analysis was performed in triplicate.

Samples were thawed under refrigeration 24 hours before color determination. Colour readings were taken after $50 \mathrm{~min}$ at room temperature $\left(22^{\circ} \mathrm{C}\right)$ using a portable digital colorimeter Konica Minolta CR-400 (Minolta Chromameter Co., Ltd., Osaka, Japan) at room temperature in the CIELab system, with the following conditions: illuminant $\mathrm{C}$, viewing angle $8^{\circ}$, and the observer's standard angle $10^{\circ}$. Measurements were made in at room-temperature, with six measurements taken at different points inside the sausages.

The real colorimetric difference (CD) of the samples of sheep meat sausages with pre-emulsified linseed oil was also determined, being calculated with the values obtained at the beginning and the end of storage $\left(-18{ }^{\circ} \mathrm{C} / 60\right.$ days $)$, using if Equation 1 second recommends Maciel et al. (2012):

$$
C D=\sqrt{\left(\left(\Delta L^{*}\right)^{2}+\left(\Delta a^{*}\right)^{2}+\left(\Delta b^{*}\right)^{2}\right)}
$$

Where,

$\Delta \mathrm{L}^{*}=\mathrm{L}^{*}{ }_{0}$ storage day $-\mathrm{L}^{*}$ storage day

$\Delta \mathrm{a}^{*}=\mathrm{a}_{0}^{*}$ storage day $-\mathrm{a}^{*}{ }_{\mathrm{x}}$ storage day

$\Delta \mathrm{b}^{*}=\mathrm{b}^{*}{ }_{0}$ storage day $-\mathrm{b}^{*}$ storage day

The determination of the water retention capacity (WRC) was carried out according to the procedures described by Herrero et al. (2005), where $2 \mathrm{~g}$ of the sample were weighed and wrapped in filter paper, and then centrifuged for $5 \mathrm{~min}$ at $4{ }^{\circ} \mathrm{C}$ at 1,500 $\times g$ in a Universal $320 \mathrm{R}$ (Hettich, Germany).

The sheer force of the sausages (four samples per treatment) was determined using a TA-XT2 texture analyzer (Stable Micro Systems Ltd., Surrey, England), with Warner Bratzler blade operating at a speed of $2.0 \mathrm{~mm} / \mathrm{s}$ in the pre-test and $10.0 \mathrm{~mm} / \mathrm{s}$ in the posttest, with a distance of $25 \mathrm{~mm}$, at a temperature of $25^{\circ} \mathrm{C}$.

Lipid oxidation was measured by determining the thiobarbituric acid reactive substances (TBARS) that were quantified in a UVVIS spectrophotometer (MINGYI-Henan China) at $532 \mathrm{nM}$ according to the methodological procedures described by Lorenzo \& Carballo (2016). The results were expressed as mg of malonaldehyde (MDA)/kg of sample.

\subsection{Statistical analysis}

The experiment was an Entirely Randomized Design (DIC) under a factorial scheme $(5 \times 4)$, with five increasing levels of addition of linseed oil $(0,10,20,30$, and $40 \%)$ and four storage times $(0,20,40$ and 60 days), totaling 20 treatments, with six samples and two repetitions. The data were submitted to Analysis of Variance (ANOVA), and the Tukey test compared the averages at $5 \%$ probability through the PROC GLM of the statistical package $\mathrm{SAS}^{\circledast}$ System (2012) Version 9.0.

\section{Results and discussion}

The proximate composition of sausage formulations is available in another manuscript of our group (Lima et al., 2021), where it can be seen that the sausages developed had high protein contents, ranging from 19.07 to $22.44 \mathrm{~g} / 100 \mathrm{~g}$, low lipid content ( 8.03 to $13.82 \mathrm{~g} / 100 \mathrm{~g}$ ) and ash content from 1.64 to $3.07 \mathrm{~g} / 100 \mathrm{~g}$. In relation to moisture content, the orthogonal contrast indicated that the control sausage did not present significant differences ( $\mathrm{p}<0.05$ ) when compared to the other formulations (Lima et al., 2021). In this sense, it can be stated that the partial replacement of animal fat by linseed oil in sheep sausages had a strong interference in the nutritional composition of the sausages.

The colorimetric parameters from $L^{\star}$ (luminosity) to $a^{*}$ and $b^{*}$ (tendency to red and yellow coloring, respectively) were influenced by the treatment $(\mathrm{P}<.0001)$, by the storage day $(\mathrm{P}<$ $.0001)$, and also by the interaction between factors $(\mathrm{P}<.0001)$ (Table 2). At day 0 , the sausage with $40 \%$ of linseed oil was the one with the darkest color (lowest value of $\mathrm{L}^{*}$ ), differing statistically from the others $(\mathrm{P}<0.05)$, since the pre-emulsified linseed oil, when interacting with the other ingredients of the formulation, it provided a lower luminosity. With the passage of storage days, it appears that the luminosity $\left(\mathrm{L}^{*}\right)$ of the control formulation increased over time $\left(-18 \pm 1{ }^{\circ} \mathrm{C}\right)$, where the averages on days 20,40 , and 60 did not differ statistically $(P>0.05)$. This same trend was observed for formulations with 20 and $40 \%$ linseed oil. In the formulation with $10 \%$ of linseed oil, it is noticed that the lowest values of luminosity were found during 40 and 60 days of storage, and in the formulation with $30 \%$ of linseed oil, no significant differences were found among the days of storage $(\mathrm{P}>0.05)$.

Different formulations also influenced $L^{\star}$ values. It was observed that the control formulation and the one containing $20 \%$ linseed oil had the highest values over time, differing significantly $(\mathrm{P}<0.05)$ from the other formulations that had the lowest values at the end of the storage period. Baek et al., (2016) also reported lower $L^{*}$ values in sausages containing linseed oil. The authors explained that this was probably a result of the high-density yellow color of the linseed oil itself, which could justify the lower values of $L^{\star}$ in the lots containing linseed oil investigated in our study. Bolger et al. (2018) also evaluated the effect of flaxseed oil as a fat substitute in chicken sausage, and found a reduction in $\mathrm{L}^{*}$ values during 14 days of refrigerated storage. In other studies, using canola (Shin et al., 2020) and sunflower (Silva et al., 2019) oil, an increase in lightness values was observed, which indicates that these differences can also be attributed to each type of oil used.

During the 60 days of storage, it is observed that for parameter $a^{*}$, all formulations were within the red color spectrum. However, at day 0 , the formulation with $30 \%$ linseed oil showed the highest average, differing statistically from the too much $(\mathrm{P}<0.05)$, indicating a greater intensity of the red color in this formulation. The control formulations and with $20 \%$ linseed oil, on the other hand, had the lowest averages, not differing statistically from each other $(\mathrm{P}>0.05)$. 
Table 2. Effect of including pre-emulsified linseed oil and storage days on color parameters on sheep meat sausages.

\begin{tabular}{|c|c|c|c|c|c|}
\hline \multirow[t]{2}{*}{ Storage (days) } & \multicolumn{5}{|c|}{ Levels of inclusion of linseed oil (\%) } \\
\hline & 0 & 10 & 20 & 30 & 40 \\
\hline \multicolumn{6}{|l|}{ Luminosity $\left(\mathrm{L}^{\star}\right)$} \\
\hline 0 & $55.82 \pm 1.76 \mathrm{bAB}$ & $55.25 \pm 0.76 \mathrm{bBC}$ & $56.70 \pm 0.52 \mathrm{bA}$ & $54.58 \pm 0.28 \mathrm{aC}$ & $53.20 \pm 0.40 \mathrm{bD}$ \\
\hline 20 & $57.03 \pm 0.76 \mathrm{aAB}$ & $56.35 \pm 0.18 \mathrm{aB}$ & $57.70 \pm 0.14 \mathrm{aA}$ & $54.77 \pm 0.30 \mathrm{aC}$ & $55.22 \pm 0.45 \mathrm{aC}$ \\
\hline 40 & $57.58 \pm 0.79 \mathrm{aA}$ & $53.90 \pm 0.56 \mathrm{cC}$ & $57.68 \pm 0.50 \mathrm{aA}$ & $54.72 \pm 0.45 \mathrm{aBC}$ & $55.15 \pm 0.17 \mathrm{aB}$ \\
\hline 60 & $57.13 \pm 0.53 \mathrm{aA}$ & $53.82 \pm 0.72 \mathrm{cB}$ & $56.97 \pm 0.22 \mathrm{abA}$ & $54.62 \pm 0.07 \mathrm{aB}$ & $54.70 \pm 0.28 \mathrm{aB}$ \\
\hline \multicolumn{6}{|l|}{ P-value } \\
\hline Levels of inclusion of linseed oil & & & $<.0001$ & & \\
\hline Storage & & & $<.0001$ & & \\
\hline Levels of inclusion of $\mathrm{f}$ linseed oil $\mathrm{x}$ Storage & & & $<.0001$ & & \\
\hline \multicolumn{6}{|l|}{$\operatorname{Red}\left(a^{*}\right)$} \\
\hline 0 & $8.18 \pm 0.25 b D$ & $9.38 \pm 0.25 b C$ & $8.33 \pm 0.25 b D$ & $13.32 \pm 0.24 \mathrm{bA}$ & $14.28 \pm 0.20 \mathrm{aA}$ \\
\hline 20 & $8.18 \pm 0.11 b D$ & $9.50 \pm 0.13 b C$ & $8.43 \pm 0.05 b D$ & $13.13 \pm 0.13 \mathrm{bA}$ & $10.22 \pm 0.28 \mathrm{cB}$ \\
\hline 40 & $9.02 \pm 0.63 \mathrm{aE}$ & $10.72 \pm 0.19 \mathrm{aC}$ & $9.68 \pm 0.21 \mathrm{aD}$ & $14.43 \pm 0.15 \mathrm{aA}$ & $11.62 \pm 0.36 \mathrm{abB}$ \\
\hline 60 & $8.38 \pm 0.13 \mathrm{bE}$ & $10.57 \pm 0.08 \mathrm{aC}$ & $9.38 \pm 0.13 \mathrm{aD}$ & $14.28 \pm 0.20 \mathrm{aA}$ & $12.10 \pm 0.72 \mathrm{aB}$ \\
\hline \multicolumn{6}{|l|}{ P-value } \\
\hline Levels of inclusion of linseed oil & & & $<.0001$ & & \\
\hline Storage & & & $<.0001$ & & \\
\hline Levels of inclusion of linseed oil $x$ Storage & & & $<.0001$ & & \\
\hline \multicolumn{6}{|l|}{ Yellow $\left(b^{*}\right)$} \\
\hline 0 & $18.03 \pm 0.30 \mathrm{bA}$ & $15.63 \pm 0.39 \mathrm{bD}$ & $17.02 \pm 0.50 \mathrm{cB}$ & $15.53 \pm 0.10 \mathrm{bD}$ & $16.55 \pm 0.40 \mathrm{cC}$ \\
\hline 20 & $19.10 \pm 0.16 \mathrm{aA}$ & $16.52 \pm 0.07 \mathrm{aD}$ & $18.52 \pm 0.07 \mathrm{aB}$ & $16.30 \pm 0.29 \mathrm{aD}$ & $17.62 \pm 0.30 \mathrm{bC}$ \\
\hline 40 & $18.15 \pm 0.16 \mathrm{bA}$ & $16.77 \pm 0.41 \mathrm{aB}$ & $18.32 \pm 0.22 \mathrm{abA}$ & $16.57 \pm 0.32 \mathrm{aB}$ & $18.25 \pm 0.27 \mathrm{aA}$ \\
\hline 60 & $18.75 \pm 0.22 \mathrm{aA}$ & $16.80 \pm 0.17 \mathrm{aC}$ & $17.93 \pm 0.10 \mathrm{bB}$ & $16.25 \pm 0.13 \mathrm{aD}$ & $17.58 \pm 0.19 \mathrm{bB}$ \\
\hline \multicolumn{6}{|l|}{ P-value } \\
\hline Levels of inclusion of linseed oil & & & $<.0001$ & & \\
\hline Storage & & & $<.0001$ & & \\
\hline Levels of inclusion of linseed oil $\mathrm{x}$ Storage & & & $<.0001$ & & \\
\hline
\end{tabular}

Different lower-case letters on the same line differ between storage days $(\mathrm{P}<0.05)$; Different capital letters in the same column differ between treatments $(\mathrm{P}<0.05)$.

Among the different batches, sausages reformulated with $30 \%$ linseed oil presented the highest values of $\mathrm{a}^{*}$, differing significantly $(\mathrm{P}<0.05)$ from the other batches during the 60 days of storage. In general, the inclusion of different levels of linseed oil positively influenced the color of the sausages, maintaining their long-term stability. A possible explanation for the differences found between the control formulation and the modified formulations may have been a better distribution of linseed oil in the protein matrix than animal bacon (Youssef \& Barbut, 2010). Similarly, Barros et al. (2020) reported an increase in $a^{*}$ values in hamburgers reformulated with tiger nut oil emulsion as animal fat substitutes. In another study, Gómez et al. (2018) also reported higher $\mathrm{a}^{*}$ values during storage compared to their control on low-fat burgers fortified with olive oil and linseed containing vitamin D3.

Regarding the $b^{*}$ coordinate, it is observed that up to 60 days of storage, the control (0\%) had the highest averages, indicating a predominance of yellow color with more intensity during the storage time $\left(-18 \pm 1^{\circ} \mathrm{C}\right)$, probably due to the opaque state of the animal fat that may have provided the most excellent yellow color retention in this treatment.

In the reformulated sausages it was possible to observe that the inclusion of linseed oil provided a significant increase $(\mathrm{P}<0.05)$ in the values of $\mathrm{b}^{*}$ comparing the beginning and the end of the storage period. This result can be explained by the yellow color tone that linseed oil has. Carvalho et al. (2020) also reported an increase in $b^{*}$ values in lamb sausages reformulated with chia, linseed and olive oils as animal fat substitutes, corroborating the results found in this work. These results also corroborate the data obtained by Bolger et al. (2018), who found an increase in yellow color during 14 days of storage $\left(4^{\circ} \mathrm{C}\right)$ when evaluating the effect of linseed oil on the quality characteristics of chicken sausage. Although linseed oil provided this increase in $b^{*}$ values in all reformulated batches, it was observed that sausages reformulated with 10 and $30 \%$ during the entire storage time, and those reformulated with 20 and $40 \%$ of oil from flaxseed on days 0,20 and 60 showed lower values compared to the control. This increase in $b^{*}$ values in the control formulation may be due to a possible myoglobin denaturation and metmyoglobin accumulation (Muela et al., 2015).

For the total colorimetric difference, it appears that there was an effect both of the treatments $(\mathrm{P}<0.001)$ and of the storage days $(\mathrm{P}<0.001)$ (Figure 1). It is observed that the sausage samples showed low values of $C D$, where they varied from 0.82 to 2.59 , indicating a low variation in color to the beginning of storage. 
As reported by Lopéz-Lopéz et al. (2009), for all colorimetric parameters $\left(L^{*}, a^{\star}\right.$, and $\left.b^{*}\right)$, the results found in this research suggest that during the sausage storage period, there is no degree of extinction of the product's color completely, which is a positive result. According to Choi et al. (2002), the color change in the samples becomes noticeable to the human eye only in values greater than 2 . Thus, according to Figure 1, it is noted that until the 20th day of storage, formulations $0,10,20$, and $30 \%$ with linseed oil presented values below 2.0, while the formulation with the highest level of linseed oil (40\%) presented CD greater than 2.0. During the storage days, an increase in $\Delta \mathrm{E}$ values is noticed for all formulations, specifically for the formulation with $40 \%$ linseed oil. In this perspective, the results obtained for CD demonstrated that the linseed oil influenced the color perception during the storage period $\left(-18 \pm 1^{\circ} \mathrm{C} / 60\right.$ days).

The water activity of the developed sausages was influenced by the treatment $(\mathrm{P}<.0001)$ and the storage days $(\mathrm{P}<.0001)$. There was no interaction between these factors $(P>0.05)$. Therefore, Table 3 shows the effects evaluated in isolation. Regarding the treatment effect, it was found that the sausage developed with the highest level of linseed oil (40\%) was the one with the lowest water activity, differing statistically from the others $(\mathrm{P}<0.05)$. Regarding the storage days, it is observed that all treatments remained stable up to 40 days, and after 60 days, there was a decrease, where the average differed statistically from the others $(\mathrm{P}<0.05)$. The water activity is directly related to the perishability of the product and can vary from 0 to 1 , so that the closer to 1 , the more free water is available in the product. Therefore, a decrease in Wa with 60 days of storage results from the product's quality.

The $\mathrm{pH}$ of the sausages in this study was influenced by the treatment $(\mathrm{P}<.0001)$, by the days $(\mathrm{P}<.0001)$, and also by the interaction between these factors $(\mathrm{P}<.0001)$ (Table 4$)$. It appears that the control formulations with 20 and $30 \%$ linseed oil showed an increase in $\mathrm{pH}$ after 40 days of storage, where at 60 days, the $\mathrm{pH}$ value did not differ statistically $(\mathrm{P}>0.05)$ from the average obtained 40 days. For formulations with 10 and $40 \%$ linseed oil, there was a decrease in $\mathrm{pH}$ after 40 days, indicating that for these formulations after 40 days of storage, acid formation may have occurred, which were responsible for promoting a decrease in $\mathrm{pH}$.

According to Fernandes et al. (2018), bioactive compounds, such as phenolic acids, can promote a specific $\mathrm{pH}$ decrease. Therefore, the formation of these acids may have occurred in formulations with 0,20 , and $30 \%$ with linseed oil only after 40 days of storage $\left(-18 \pm 1{ }^{\circ} \mathrm{C}\right)$. During the storage period, the values found for all formulations were similar to those reported in the literature for this type of product (Lopéz-Lopéz et al., 2009; Choi et al., 2010, Sousa et al., 2017), where the control sausage was the one with the lowest values during storage, indicating that the levels of linseed oil added to the sausages contributed to changes in the $\mathrm{pH}$ of the samples. When evaluating how to add linseed oil to the quality characteristics of chicken sausages, Bolger et al. (2018) found an increase in moisture content for all treatments.

The content moisture of the sausages developed was influenced by the treatment $(\mathrm{P}<.0001)$ and the interaction between the treatment and the storage days $(\mathrm{P}<.0001)$, however, there was no influence only from the days effect $(\mathrm{P}>0.05)$ (Table 5). Until day 20 of storage, there was a significant increase $(\mathrm{P}<0.05)$ in moisture content for the control formulation, and later it remained statistically stable until the end of storage. The batches reformulated with 10 and $20 \%$ linseed oil were not changed during the entire storage period. However, the lots containing the highest levels of linseed oil (30 and 40\%) showed a dropin moisture values between day zero and 20, later showing a significant increase $(\mathrm{P}<0.05)$ up to 60 days. Comparing the different batches, it was observed that sausages reformulated with $20 \%$ linseed oil presented a significant difference $(\mathrm{P}<0.05)$ with the control formulation. In addition, sausages reformulated with 30 and $40 \%$ linseed oil had the lowest moisture values compared to the other formulations (control, 10 and 20\% linseed

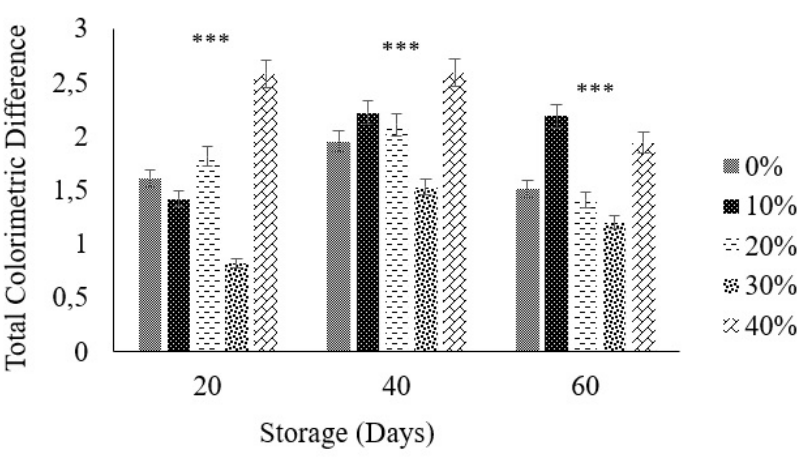

Figure 1. Total colorimetric difference on sheep meat sausages with pre-emulsified linseed oil during storage $\left(-18^{\circ} \mathrm{C} \pm 1{ }^{\circ} \mathrm{C} / 60\right.$ days $)$. $* * *(p<0.001)$, indicate significant differences between samples in days of storage.

Table 3. Effect of including pre-emulsified linseed oil and storage days on water activity on sheep meat sausages.

\begin{tabular}{ll}
\hline \multicolumn{1}{c}{ Effects } & Water activity \\
\hline Levels of inclusion of linseed oil (\%) & \\
0 & $0.995 \mathrm{a}$ \\
10 & $0.993 \mathrm{ab}$ \\
20 & $0.993 \mathrm{ab}$ \\
30 & $0.988 \mathrm{ab}$ \\
40 & $0.983 \mathrm{~b}$ \\
Mean standard error & 0.004 \\
Storage (days) & \\
0 & $0.986 \mathrm{a}$ \\
20 & $0.986 \mathrm{a}$ \\
40 & $0.986 \mathrm{a}$ \\
60 & $0.924 \mathrm{~b}$ \\
Mean standard error & 0.005 \\
P-value & \\
Levels of inclusion of linseed oil & 0.0451 \\
Storage & $<.0001$ \\
Levels of inclusion of linseed oil x Storage & 0.6235 \\
\hline
\end{tabular}

Lower case letters different from each other on the same line indicate significant differences by the Tukey test $(\mathrm{P}<0.05)$. 
Table 4. Effect of including pre-emulsified linseed oil and storage days on $\mathrm{pH}$ on sheep meat sausages.

\begin{tabular}{|c|c|c|c|c|c|}
\hline \multirow{2}{*}{ Storage (days) } & \multicolumn{5}{|c|}{ Levels of inclusion of linseed oil (\%) } \\
\hline & 0 & 10 & 20 & 30 & 40 \\
\hline 0 & $6.38 \pm 0.02 \mathrm{cD}$ & $6.48 \pm 0.02 \mathrm{cAB}$ & $6.52 \pm 0.03 \mathrm{bA}$ & $6.46 \pm 0.01 \mathrm{cBC}$ & $6.42 \pm 0.01 c \mathrm{CD}$ \\
\hline 20 & $6.50 \pm 0.00 \mathrm{bB}$ & $6.51 \pm 0.02 \mathrm{cB}$ & $6.54 \pm 0.03 \mathrm{bB}$ & $6.52 \pm 0.02 \mathrm{bB}$ & $6.61 \pm 0.01 \mathrm{abA}$ \\
\hline 40 & $6.65 \pm 0.01 \mathrm{aB}$ & $6.69 \pm 0.01 \mathrm{aA}$ & $6.67 \pm 0.03 \mathrm{aAB}$ & $6.63 \pm 0.00 \mathrm{aB}$ & $6.65 \pm 0.04 \mathrm{aB}$ \\
\hline 60 & $6.64 \pm 0.02 \mathrm{aAB}$ & $6.62 \pm 0.01 \mathrm{bB}$ & $6.67 \pm 0.01 \mathrm{aA}$ & $6.62 \pm 0.01 \mathrm{aB}$ & $6.59 \pm 0.02 \mathrm{bB}$ \\
\hline \multicolumn{6}{|c|}{$P$-value } \\
\hline Levels of inclusion of linseed oil & & & 0.0003 & & \\
\hline Storage & & & $<.0001$ & & \\
\hline Levels of inclusion of linseed oil x Storage & & & 0.0325 & & \\
\hline
\end{tabular}

Different lower-case letters on the same line differ between storage days $(\mathrm{P}<0.05)$; Different capital letters in the same column differ between treatments $(\mathrm{P}<0.05)$

Table 5. Effect of including pre-emulsified linseed oil and storage days on moisture on sheep meat sausages.

\begin{tabular}{|c|c|c|c|c|c|}
\hline \multirow{2}{*}{ Storage (days) } & \multicolumn{5}{|c|}{ Levels of inclusion of linseed oil (\%) } \\
\hline & 0 & 10 & 20 & 30 & 40 \\
\hline 0 & $64.60 \pm 0.01 \mathrm{bAB}$ & $65.63 \pm 0.84 \mathrm{aA}$ & $65.43 \pm 0.21 \mathrm{aAB}$ & $64.22 \pm 0.74 \mathrm{aB}$ & $61.08 \pm 0.31 \mathrm{bC}$ \\
\hline 20 & $65.82 \pm 0.42 \mathrm{aA}$ & $65.43 \pm 0.72 \mathrm{aA}$ & $65.26 \pm 0.24 \mathrm{aA}$ & $62.95 \pm 0.62 \mathrm{bB}$ & $62.57 \pm 0.74 \mathrm{aB}$ \\
\hline \multirow[t]{2}{*}{60} & $66.12 \pm 0.84 \mathrm{aA}$ & $65.95 \pm 0.38 \mathrm{aA}$ & $64.47 \pm 0.34 \mathrm{aB}$ & $64.16 \pm 0.11 \mathrm{aB}$ & $62.67 \pm 0.39 \mathrm{aC}$ \\
\hline & & P-value & & & \\
\hline Levels of inclusion of linseed oil $\mathrm{x}$ Storage & & & 0.0325 & & \\
\hline
\end{tabular}

Different lower-case letters on the same line differ between storage days $(\mathrm{P}<0.05)$; Different capital letters in the same column differ between treatments $(\mathrm{P}<0.05)$.

oil). These results agree with those reported by Carvalho et al. (2020) where they evaluated the effect of replacing pork fat with vegetable oils (chia, flaxseed and olive) in cooked lamb sausages. In another study, Franco et al. (2019) also reported lower moisture contents in frankfurter sausages reformulated with linseed oil based oleogel. However, the authors of the two studies did not explain the possible causes of this reduction in their reformulated products. In other studies, using different vegetable oils in meat products, such as soybean oil (Paglarini et al., 2019), chia and linseed (Heck et al., 2019), linseed (Alejandre et al., 2016), canola (Monteiro et al., 2017), sunflower (Silva et al., 2019), olive and canola (Afshari et al., 2017) and flaxseed and peanut (Nacak et al., 2021) were reported higher moisture contents. Therefore, further studies are needed to more comprehensively investigate the influence of linseed oil on the moisture content of reformulated meat products during storage.

The water retention capacity was influenced by the treatment $(\mathrm{P}<.0001)$, the storage days $(\mathrm{P}<.0001)$, and also the interaction between these factors $(P<.0001)$ (Table 6). At days 0 , as the levels of animal fat substitution with pre-emulsified linseed oil increased, the sausages developed showed a greater capacity to retain water, especially formulations with 30 and $40 \%$ linseed oil. The control sausage ( $0 \%$ linseed oil) showed the lowest WRC values throughout the storage period. In general, sausages developed with linseed oil showed an increase in WRC over the storage period, where sausages developed with the highest oil levels (30 and 40\%) were the formulations with the highest WRC during the entire storage period. Therefore, these results indicate that the linseed oil pre-emulsified with isolated soy protein seemed to be efficient in providing higher WRC to sausages, which is, in fact, desirable since WRC is an essential technological parameter to assess the quality of the final product.

Lipid oxidation is considered one of the main problems of the deterioration of meat products. Thus, it is noted that the TBARS values were affected by the treatment $(\mathrm{P}<.0001)$ and by the storage days $(\mathrm{P}<.0001)$, with an interaction between these factors $(\mathrm{P}<.0001)$ (Table 7). It was observed that the control formulation, and the formulations containing 10,30 and 40\% linseed oil presented a significant increase $(\mathrm{P}<0.05)$ in TBARS values up to 20 days of storage. In the formulation containing $20 \%$ linseed oil, this increase was observed up to 40 days. Subsequently, all batches had a reduction in TBARS values, but in sausages reformulated with 20 and $40 \%$ linseed oil, this reduction was not significant $(\mathrm{P}>0.05)$. This downward trend in TBARS values over time may be associated with malonaldehyde decomposition by other products such as alcohols, ketones and acids that do not react with thiobarbituric acid, or also, may be associated with the interaction of malonaldehyde with polymers such as proteins (Yunes et al., 2013). This same behavior was reported by Nacak et al. (2021) in sausages added with gel emulsions based on linseed oil and peanuts during 90 days of storage.

Despite this reduction in TBARS values in all formulations, batches reformulated with linseed oil showed a higher rate of lipid oxidation from the beginning of storage compared to the control formulation (without addition of linseed oil). Among 
Table 6. Effect of including pre-emulsified linseed oil and storage days on the water retention capacity on sheep meat sausages.

\begin{tabular}{|c|c|c|c|c|c|}
\hline \multirow{2}{*}{ Storage (days) } & \multicolumn{5}{|c|}{ Levels of inclusion of linseed oil (\%) } \\
\hline & 0 & 10 & 20 & 30 & 40 \\
\hline 0 & $83.18 \pm 0.31 \mathrm{aD}$ & $83.32 \pm 0.12 \mathrm{bCD}$ & $85.67 \pm 0.33 \mathrm{aBC}$ & $87.40 \pm 0.69 \mathrm{bAB}$ & $89.33 \pm 0.16 \mathrm{bA}$ \\
\hline 20 & $81.33 \pm 0.65 \mathrm{aD}$ & $85.59 \pm 0.94 \mathrm{abC}$ & $84.95 \pm 0.44 \mathrm{aC}$ & $91.14 \pm 0.33 \mathrm{aA}$ & $88.25 \pm 0.29 \mathrm{bB}$ \\
\hline 40 & $83.26 \pm 0.80 \mathrm{aC}$ & $87.26 \pm 0.14 \mathrm{aB}$ & $86.74 \pm 0.54 \mathrm{aB}$ & $92.24 \pm 0.34 \mathrm{aA}$ & $92.58 \pm 0.79 \mathrm{aA}$ \\
\hline 60 & $79.00 \pm 0.33 \mathrm{bD}$ & $\begin{array}{c}85.51 \pm 0.17 \mathrm{abC} \\
P \text {-value }\end{array}$ & $86.12 \pm 0.44 \mathrm{aBC}$ & $90.17 \pm 0.23 \mathrm{aA}$ & $88.51 \pm 0.27 \mathrm{bAB}$ \\
\hline Levels of inclusion of linseed oil & & & 0.0004 & & \\
\hline Storage & & & $<.0001$ & & \\
\hline Levels of inclusion of linseed oil $\mathrm{x}$ Storage & & & 0.0025 & & \\
\hline
\end{tabular}

Table 7. Effect of including pre-emulsified linseed oil and storage days on lipid oxidation (TBARS) on sheep meat sausages.

\begin{tabular}{|c|c|c|c|c|c|}
\hline \multirow{2}{*}{ Storage (days) } & \multicolumn{5}{|c|}{ Levels of inclusion of linseed oil (\%) } \\
\hline & 0 & 10 & 20 & 30 & 40 \\
\hline 0 & $0.17 \pm 0.01 \mathrm{bB}$ & $0.18 \pm 0.01 \mathrm{cB}$ & $0.19 \pm 0.01 \mathrm{bB}$ & $0.20 \pm 0.01 \mathrm{~dB}$ & $0.28 \pm 0.03 \mathrm{bA}$ \\
\hline 20 & $0.24 \pm 0.01 \mathrm{aD}$ & $0.31 \pm 0.02 \mathrm{aC}$ & $0.21 \pm 0.00 \mathrm{abD}$ & $0.36 \pm 0.03 \mathrm{aB}$ & $0.42 \pm 0.00 \mathrm{aA}$ \\
\hline 40 & $0.23 \pm 0.01 \mathrm{aC}$ & $0.28 \pm 0.01 \mathrm{aB}$ & $0.23 \pm 0.01 \mathrm{aC}$ & $0.33 \pm 0.02 \mathrm{bA}$ & $0.27 \pm 0.01 \mathrm{bB}$ \\
\hline 60 & $0.16 \pm 0.00 \mathrm{bC}$ & $0.21 \pm 0.02 \mathrm{bB}$ & $0.21 \pm 0.00 \mathrm{abB}$ & $0.25 \pm 0.01 \mathrm{cA}$ & $0.26 \pm 0.01 \mathrm{bA}$ \\
\hline \multicolumn{6}{|c|}{$P$-value } \\
\hline Levels of inclusion of linseed oil & & & $<.0001$ & & \\
\hline Storage & & & $<.0001$ & & \\
\hline Levels of inclusion of linseed oil x Storage & & & 0.0025 & & \\
\hline
\end{tabular}

Different lower-case letters on the same line differ between storage days $(\mathrm{P}<0.05)$; Different capital letters in the same column differ between treatments $(\mathrm{P}<0.05)$.

the different batches, it was observed that sausages containing the highest levels of linseed oil (30 and 40\%) had the highest levels of lipid oxidation, confirmed by significant difference (P $<0.05$ ) between the formulations in each period of storage. This increase in lipid oxidation in reformulated batches was already expected because the replacement of saturated fat with vegetable oils rich in unsaturated fatty acids increases the lipid oxidation of meat products (Lorenzo et al., 2016; Dominguez et al., 2017; Domínguez et al., 2019). However, all formulations had TBARS values well below the threshold ( $2.0 \mathrm{mg} / \mathrm{MDA}$ per gram of meat) minimum required to detect negative changes in the organoleptic characteristics of meat products (Delgado-Pando et al., 2012). Similar results were reported by Heck et al. (2019) who used gel emulsions prepared with chia oil and flaxseed to replace pork bacon in burgers, and observed an increase in TBARS values, where the highest levels of oxidation were presented by the batch containing the highest level of emulsion, and they associated this result with the high degree of susceptibility of the vegetable oils to oxidation. In another study Gómez-Estaca et al. (2019) evaluated the combination of vegetable oils (olive oil, flaxseed and fish) structured with ethylcellulose and beeswax as animal fat substitutes in pork burgers and observed higher levels of oxidation for the formulations modified. Likewise, Utama et al. (2019) observed an increase in TBARS values at the beginning of storage, and then a reduction towards the end in chicken sausage prepared with pre-emulsified perilla and canola oil. The authors explained that this trend of decreasing malonaldehyde (MDA) concentration during storage is due to the conversion of MDA into other products such as organic acids and alcohols, corroborating the same trend reported in our study in sheep sausages (Utama et al., 2019).

\section{Conclusions}

The process of replacing animal fat with pre-emulsified linseed oil in sheep meat sausages and the storage days directly affect the colorimetric, physicochemical, and lipid oxidation characteristics. However, this study suggests that sheep meat sausages can be made with 40 pre-emulsified linseed oil to replace animal fat, and in up to 60 days of storage $\left(-18 \pm 1{ }^{\circ} \mathrm{C}\right)$, the product has attributes colorimetric, physicochemical, and lipid oxidation quality.

\section{References}

Afshari, R., Hosseini, H., Khaneghah, A. M., \& Khaksar, R. (2017). Physico-chemical properties of functional low-fat beef burgers: fatty acid profile modification. $L W T, 78,325-331$. http://dx.doi. org/10.1016/j.lwt.2016.12.054.

Alejandre, M., Poyato, C., Ansorena, D., \& Astiasarán, I. (2016). Linseed oil gelled emulsion: a successful fat replacer in dry fermented sausages. Meat Science, 121, 107-113. http://dx.doi.org/10.1016/j. meatsci.2016.05.010. PMid:27300155.

Association of Official Analytical Chemists - AOAC. (2010). Official methods of analysis (18th ed.). Washington, D.C: AOAC.

Baek, K. H., Utama, D. T., Lee, S. G., An, B. K., \& Lee, S. K. (2016). Effects of replacing pork back fat with canola and flaxseed oils on 
physicochemical properties of emulsion sausages from spent layer meat. Asian-Australasian Journal of Animal Sciences, 29(6), 865.

Barros, B. J., Munekata, P. E., Carvalho, F. A. L., Pateiro, M., Barba, F. J., Domínguez, R., \& Lorenzo, J. M. (2020). Use of tiger nut (Cyperus esculentus L.) oil emulsion as animal fat replacement in beef burgers. Foods, 9(1), 44.

Bolger, Z., Brunton, N. P., \& Monahan, F. J. (2018). Impact of inclusion of flaxseed oil (pre-emulsified or encapsulated) on the physical characteristics of chicken sausages. Journal of Food Engineering, 230, 39-48. http://dx.doi.org/10.1016/j.jfoodeng.2018.02.026.

Carvalho, F. A. L., Munekata, P. E., Pateiro, M., Campagnol, P. C., Domínguez, R., Trindade, M. A., \& Lorenzo, J. M. (2020). Effect of replacing backfat with vegetable oils during the shelf-life of cooked lamb sausages. LWT, 122, 109052. http://dx.doi.org/10.1016/j. lwt.2020.109052.

Choi, M. H., Kim, H. S., \& Lee, H. S. (2002). Effects of ascorbic acid retention on juice color and pigment stability in blood orage (Citrus sinensis) juice during refrigerated storage. Food Research International, 35(8), 753-759. http://dx.doi.org/10.1016/S0963-9969(02)00071-6.

Choi, Y. S., Choi, J. H., Han, D. J., Kim, H. Y., Lee, M. A., Jeong, J. Y., Chung, H.,\& Kim, C. J. (2010). Effects of replacing pork back fat with vegetable oils and rice bran fiber on the quality of reduced-fat frankfurters. Meat Science, 84(3), 557-563. http://dx.doi.org/10.1016/j. meatsci.2009.10.012. PMid:20374824.

Delgado-Pando, G., Cofrades, S., Ruiz-Capillas, C., Triki, M., \& JiménezColmenero, F. (2012). Enriched n- 3 PUFA/konjac gel low-fat pork liver pâté: lipid oxidation, microbiological properties and biogenic amine formation during chilling storage. Meat Science, 92(4), 762-767. http://dx.doi.org/10.1016/j.meatsci.2012.06.035. PMid:22795631.

Domínguez, R., Pateiro, M., Gagaoua, M., Barba, F. J., Zhang, W., \& Lorenzo, J. M. (2019). A comprehensive review on lipid oxidation in meat and meat products. Antioxidants, 8(10), 429. http://dx.doi. org/10.3390/antiox8100429. PMid:31557858.

Dominguez, R., Pateiro, M., Munekata, P. E. S., Campagnol, P. C. B., \& Lorenzo, J. M. (2017). Influence of partial pork backfat replacement by fish oil on nutritional and technological properties of liver pâté. European Journal of Lipid Science and Technology, 119(5), 1600178.

Fernandes, R. D. P. P., Trindade, M. A., Lorenzo, J. M., \& Melo, M. P. (2018). Assessment of the stability of sheep sausages with the addition of different concentrations of Origanum vulgare extract during storage. Meat science, 137, 244-257.

Folch, J., Lees, M., \& Stanley, G. H. S. (1957). A simple method for the isolation and purification of total lipides from animal tissues. The Journal of Biological Chemistry, 226(1), 497-509. http://dx.doi. org/10.1016/S0021-9258(18)64849-5. PMid:13428781.

Franco, D., Martins, A. J., López-Pedrouso, M., Purriños, L., Cerqueira, M. A., Vicente, A. A., \& Lorenzo, J. M. (2019). Strategy towards replacing pork backfat with a linseed oleogel in frankfurter sausages and its evaluation on physicochemical, nutritional, and sensory characteristics. Foods, 8(9), 366.

Garcia-Santos, M. S. L., Conceição, F. S., Villas Boas, F., Souza, B. M. S., \& Barretto, A. C. S. (2019). Effect of the addition of resistant starch in sausage with fat reduction on the physicochemical and sensory properties. Food Science and Technology, 39(Suppl. 2), 491-497. http://dx.doi.org/10.1590/fst.18918.

Gómez, I., Sarriés, M. V., Ibañez, F. C., \& Beriain, M. J. (2018). Quality characteristics of a low-fat beef patty enriched by polyunsaturated fatty acids and vitamin D3. Journal of Food Science, 83(2), 454-463. http://dx.doi.org/10.1111/1750-3841.14043. PMid:29350749.
Gómez-Estaca, G. J., Pintado, T., Jiménez-Colmenero, F., \& Cofrades, S. (2019). Assessment of a healthy oil combination structured in ethyl cellulose and beeswax oleogels as animal fat replacers in lowfat, PUFA-enriched pork burgers. Food and Bioprocess Technology, 12(6), 1068-1081. http://dx.doi.org/10.1007/s11947-019-02281-3.

Heck, R. T., Saldaña, E., Lorenzo, J. M., Correa, L. P., Fagundes, M. B., Cichoski, A. J., Menezes, C. R., Wagner, R., \& Campagnol, P. C. B. (2019). Hydrogelled emulsion from chia and linseed oils: a promising strategy to produce low-fat burgers with a healthier lipid profile. Meat Science, 156, 174-182. http://dx.doi.org/10.1016/j. meatsci.2019.05.034. PMid:31200329.

Herrero, A. M., Carmona, P., García, M. L., Solas, M. T., \& Careche, M. (2005). Ultrastructural changes and structure and mobility of myowater in frozen-stored hake (Merluccius merluccius L.) muscle: relationship with functionality and texture. Journal of Agricultural and Food Chemistry, 53(7), 2558-2566. http://dx.doi.org/10.1021/ jf0490706. PMid:15796595.

Inmanee, P., Kamonpatana, P., \& Pirak, T. (2019). Ohmic heating effects on Listeria monocytogenes inactivation, and chemical, physical, and sensory characteristic alterations for vacuum packaged sausage during post pasteurization. $L W T, 108,183-189$. http://dx.doi. org/10.1016/j.lwt.2019.03.027.

Kang, Z. L., Chen, F. S., \& Ma, H. J. (2016). Effect of pre-emulsified soy oil with soy protein isolate in frankfurters: a physical-chemical and Raman spectroscopy study. LWT, 74, 465-471. http://dx.doi. org/10.1016/j.lwt.2016.08.011.

Lima, T. L. S., Costa, G. F., Araújo, I. B. S., Cruz, G. R. B., Ribeiro, N. L., Beltrão, E. M. Fo, Domínguez, R., \& Lorenzo, J. M. (2021). Preemulsioned linseed oil as animal fat replacement in sheep meat sausages: microstructure and physicochemical properties. Journal of Food Processing and Preservation, 45(1), e15051. http://dx.doi. org/10.1111/jfpp.15051.

López-López, I., Cofrades, S., \& Jiménez-Colmenero, F. (2009). Low-fat frankfurters enriched with n-3 PUFA and edible seaweed: Effects of olive oil and chilled storage on physicochemical, sensory and microbial characteristics. Meat Science, 83, 148-154.

Lorenzo, J. M., \& Carballo, J. (2016). Influence of anatomical retail cut on physicochemical and sensory characteristics of foal "cecina". International Journal of Food Properties, 19(4), 802-813. http://dx.doi. org/10.1080/10942912.2015.1045070.

Lorenzo, J. M., Munekata, P. E. S., Pateiro, M., Campagnol, P. C. B., \& Domínguez, R. (2016). Healthy Spanish salchichón enriched with encapsulated $\mathrm{n}-3$ long chain fatty acids in the konjac glucomannan matrix. Food Research International, 89(Pt 1), 289-295. http://dx.doi. org/10.1016/j.foodres.2016.08.012. PMid:28460917.

Maciel, V. B. V., Yoshida, C. M. P., \& Franco, T. T. (2012). Development of a prototype of a colourimetric temperature indicator for monitoring food quality. Journal of Food Engineering, 111(1), 21-27. http:// dx.doi.org/10.1016/j.jfoodeng.2012.01.037.

Monteiro, G. M., Souza, X. R., Costa, D. P. B., Faria, P. B., \& Vicente, J. (2017). Partial substitution of pork fat with canola oil in Toscana sausage. Innovative Food Science \& Emerging Technologies, 44, 2-8. http://dx.doi.org/10.1016/j.ifset.2017.07.013.

Mozaffarian, D., Ascherio, A., Hu, F. B., Stampfer, M. J., Willett, W. C., Siscovick, D. S., \& Rimm, E. B. (2005). Interplay between different polyunsaturated fatty acids and risk of coronary heart disease in men. Circulation, 111(2), 157-164. http://dx.doi.org/10.1161/01. CIR.0000152099.87287.83. PMid:15630029.

Muela, E., Monge, P., Sañudo, C., Campo, M. M., \& Beltrán, J. A. (2015). Meat quality of lamb frozen stored up to 21 months: instrumental 
analyses on thawed meat during display. Meat Science, 102, 35-40. http://dx.doi.org/10.1016/j.meatsci.2014.12.003. PMid:25529287.

Nacak, B., Öztürk-Kerimoğlu, B., Yıldız, D., Çağındı, Ö., \& Serdaroğlu, M. (2021). Peanut and linseed oil emulsion gels as potential fat replacer in emulsified sausages. Meat Science, 176, 108464. http:// dx.doi.org/10.1016/j.meatsci.2021.108464. PMid:33618129.

Paglarini, S. C., Furtado, G. F., Honório, A. R., Mokarzel, L., Vidal, V. A. S., Ribeiro, A. P. B., \& Pollonio, M. A. R. (2019). Functional emulsion gels as pork back fat replacers in Bologna sausage. Food Structure, 20, 100-105.

Qi, W., Wu, J., Shu, Y., Wang, H., Rao, W., Xu, H.-N., \& Zhang, Z. (2020). Microstructure and physiochemical properties of meat sausages based on nanocellulose-stabilized emulsions. International Journal of Biological Macromolecules, 152, 567-575. http://dx.doi. org/10.1016/j.ijbiomac.2020.02.285. PMid:32112849.

Rallidis, L. S., Paschos, G., Liakos, G. K., Velissaridou, A. H., Anastasiadis, G., \& Zampelas, A. (2003). Dietary a-linolenic acid decreases $\mathrm{C}$-reactive protein, serum amyloid A and interleukin-6 in dyslipidaemic patients. Atherosclerosis, 167(2), 237-242. http:// dx.doi.org/10.1016/S0021-9150(02)00427-6. PMid:12818406.

Shin, D. J., Lee, H. J., Lee, D., Jo, C., \& Choe, J. (2020). Fat replacement in chicken sausages manufactured with broiler and old laying hens by different vegetable oils. Poultry Science, 99(5), 2811-2818. http:// dx.doi.org/10.1016/j.psj.2020.01.008. PMid:32359618.

Silva, S. L., Amaral, J. T., Ribeiro, M., Sebastião, E. E., Vargas, C., Franzen, F. L., Schneider, G., Lorenzo, J. M., Fries, L. L. M., Cichoski, A. J., \& Campagnol, P. C. B. (2019). Fat replacement by oleogel rich in oleic acid and its impact on the technological, nutritional, oxidative, and sensory properties of Bologna-type sausages. Meat Science, 149, 141148. http://dx.doi.org/10.1016/j.meatsci.2018.11.020. PMid:30528718.
Sousa, S. C., Fragoso, S. P., Penna, C. R. A., Arcanjo, N. M. O., Silva, F. A. P., Ferreira, V. C. S., Barreto, M. D. S., \& Araújo, I. B. S. (2017). Quality parameters of frankfurter-type sausages with partial replacement of fat by hydrolyzed collagen. $L W T, 76,320-325$. http:// dx.doi.org/10.1016/j.lwt.2016.06.034.

Teixeira, A., Silva, S., \& Rodrigues, S. (2019). Advances in sheep and goat meat products research. Advances in Food and Nutrition Research, 87, 305-370. http://dx.doi.org/10.1016/bs.afnr.2018.09.002. PMid:30678817.

Utama, D. T., Jeong, H. S., Kim, J., Barido, F. H., \& Lee, S. K. (2019). Fatty acid composition and quality properties of chicken sausage formulated with pre-emulsified perilla-canola oil as an animal fat replacer. Poultry Science, 98(7), 3059-3066. http://dx.doi.org/10.3382/ ps/pez105. PMid:30877751.

Youssef, M. K., \& Barbut, S. (2010). Physicochemical effects of the lipid phase and protein level on meat emulsion stability, texture, and microstructure. Journal of Food Science, 75(2), S108-S114. http:// dx.doi.org/10.1111/j.1750-3841.2009.01475.x. PMid:20492255.

Yunes, J. F. F., Cavalheiro, C. P., Milani, L. I. G., Scheeren, M. B., Blazquez, F. J. H., Ballus, C. A., \& Terra, N. N. (2013). Effect of replacing pork fat with vegetable oils on the quality, oxidative stability and microstructure characteristics of mortadella. Semina: Agricultural Sciences, 34(3), 1205-1216.

Zeng, L., Ruan, M., Liu, J., Wilde, P., Naumova, E. N., Mozaffarian, D., \& Zhang, F. F. (2019). Trends in processed meat, unprocessed red meat, poultry, and fish consumption in the United States, 1999-2016. Journal of the Academy of Nutrition and Dietetics, 119(7), 1085-1098. http://dx.doi.org/10.1016/j.jand.2019.04.004. PMid:31234969. 